\title{
Toxicity And Accumulation of Lead And Cadmium In The Land Snail, Archachatina Papyracea In A Tropical Alfisol From Southwestern Nigeria
}

\section{Olugbenga John Owojori}

Obafemi Awolowo University

\section{Michael Awodiran}

Obafemi Awolowo University

\section{Oluwadunsin Ajana}

Obafemi Awolowo University

Olukayode Jegede ( $\square$ kayode.jegede@wur.nl )

Wageningen University and Research https://orcid.org/0000-0003-2667-3396

\section{Research Article}

Keywords: Snail, metals, Archachatina papyracea, accumulation, tropics, toxicity.

Posted Date: October 20th, 2021

DOI: https://doi.org/10.21203/rs.3.rs-928711/v1

License: (1) This work is licensed under a Creative Commons Attribution 4.0 International License. Read Full License

Version of Record: A version of this preprint was published at Environmental Science and Pollution Research on February 9th, 2022. See the published version at https://doi.org/10.1007/s11356-02218947-z. 


\section{Abstract}

Snails are an important link in the transfer of contaminants, especially metals in the food chain. Yet, few studies have examined the toxicity and accumulation of metals in snails in the tropics. This study assessed the toxicity and accumulation of two non-essential metals (cadmium and lead) to the tropical snail Archachatina papyracea. Specimens of the snail A. papyracea were exposed in a loamy soil collected from Ile-Ife, Nigeria and spiked with varying concentrations of $\mathrm{Cd}$ and $\mathrm{Pb}$ over 28 days. Survival and weight change of snails were monitored weekly while tissue accumulation was assessed at the end of the 28-day period. Survival was a more sensitive endpoint than the weight change of snails. The $\mathrm{Cd}$ median lethal concentration (LC50) value was $93 \pm 4.4 \mathrm{mg} / \mathrm{kg}$, while the median effect concentration (EC50) for snail weight change was $131 \pm 41 \mathrm{mg} / \mathrm{kg}$. For Pb, LC50 value was $1121 \pm 457 \mathrm{mg} / \mathrm{kg}$ while the EC50 value for weight change was higher at $4541 \pm 1180 \mathrm{mg} / \mathrm{kg}$. Therefore, Cd was a factor of about 10 to 30 more toxic than $\mathrm{Pb}$, consistent with findings on the relative toxicity of $\mathrm{Cd}$ and $\mathrm{Pb}$ to other soil organisms, including earthworms, springtails, and mites. Although not included initially as an endpoint, egg production in the snails decreased with increasing $\mathrm{Cd}$ and $\mathrm{Pb}$ concentrations in the substrate. Metal analysis of the foot and visceral mass of surviving snails showed progressive accumulation of $\mathrm{Cd}$ and $\mathrm{Pb}$ as concentration increased, showing the tendency to use body residue of $A$. papyracea as an indicator of metal pollution. It further suggests the role of this snail species in above-ground metal transfer in the food chain and highlights the potential danger for human consumption.

\section{Introduction}

Heavy metal pollution has become a great source of concern, especially through contamination of soil and groundwater via point and non-point sources (Edwards, 2002). Metals can persist in the soil for a long period of time, hence creating long-term hazards. Soil contamination with metals results in accumulation and subsequent toxicity to plants (Zayed et al. 1998; Gimmler et al. 2002), microbes and invertebrates (Owojori et al. 2009a). In metal-contaminated industrial soils, reports of loss of invertebrate species diversity are commonly reported (Spurgeon et al. 1994; Jones 1991). In earthworms, heavy metals can cause spermatozoa damage thereby reducing the earthworm sperm count (Cikutovic et al. 1993; Reinecke and Reinecke 1997), which negatively affects reproduction (Spurgeon et al. 1994). Abnormal environmental metal concentrations have been reported to adversely affect the feeding, growth, reproduction, and general physiology of molluscs (Bonally De Calventi 1965; Calabrese et al. 1977).

One way by which organisms interact with metals in the environment is through bioaccumulation. Metals are non-degradable and tend to bioaccumulate in soil biota. For example, Owojori and Siciliano (2012) reported a substantial accumulation of cadmium and lead in soil mite, Oppia nitens. In two genera of earthworms, Amynthas and Metaphire exposed to a metal-contaminated site, cadmium's bioaccumulation factor was reported to be more than ten (Wang et al. 2018). In a study where snails, Helix aspersa was exposed to a metal-polluted site and compared to a non-polluted site, a substantial accumulation of copper, zinc, lead and cadmium was reported (Gomot de Vaufleury and Pihan 2000). The bioaccumulation potential of soil biota, demonstrates that bioaccumulation is a major process 
through which increased levels of metals are transferred across food chains, creating ecological and public health problems. Therefore, it is important to always determine the capacity for bioaccumulation and the toxic effect of heavy metals on organisms, especially edible ones like snails, to assess potential risks to human health. Moreover, it is important to note that molluscs can accumulate higher metal ions concentrations than other invertebrate groups (Beaby and Eaves 1983).

In a study of invertebrates in the vicinity of the Avon-mouth smelting works (UK), the snail, Helix aspersa was not found in regions of extremely high metal pollution that are close to the factory (Jones 1991). One way to explain this phenomenon was that there was direct poisoning of snails by metals ingested with food. However, in laboratory experiments, where snails and slugs were exposed to very high heavy metal concentrations through food, they have proved to be tolerant (Marigomez et al. 1986). The authors did not find any effect of $\mathrm{Zn}$ or $\mathrm{Cu}$ in diets on the mortality of the slug Arionater at concentrations as high as $1000 \mathrm{mg} / \mathrm{kg}$. Similarly, Russell et al. (1981) found no mortality in Helix aspersa that were fed on a diet containing up to $1000 \mathrm{mg} \mathrm{Cd} / \mathrm{kg}$ food. This high tolerance in the molluscs, is possibly due to the efficient binding of metal ions by metallothioneins (Taylor et al., 1988) and deposition in insoluble intracellular granules (Howard et al. 1981). For example, Beeby and Richmond (1989) suggested that the snail shell could act as a temporary 'sink' for $\mathrm{Pb}$. Terrestrial molluscs may also possess other physiological mechanisms to regulate metal assimilation from food sources (Berger and Dallinger 1989).

Most of these studies were conducted with temperate snail species, and very few studies have been conducted on the toxicity of metals to tropical snail species. Notably, among the snail species studied in the tropics are the giant land snail, Archachatina marginata. Their metal bioaccumulation tendencies in the field have been widely reported (Wegwu and Wigwe 2006; Ebenso and Ologhobo 2008). Some studies have also reported metal toxicity to A. marginata (Otitoloju et al. 2009). Ugokwe et al. (2020) also studied the effect of contamination on another tropical land snail species, Limicolaria aurora, where it reported induction of oxidative stress enzymes when exposed to waste leachates containing metals compared to the non-exposed snails. Archachatina papyracea is another known giant land snail species, but metal toxicity to this snail and metal accumulation is largely unknown. In Nigeria and many other countries in the South, $\mathrm{Pb}$ and $\mathrm{Cd}$ are introduced into the environment through paint flakes, burning of fossil fuels which contains these metals as anti-knocking additives, and through metal mining activities (Yakeen and Onifade 2012; Adeyi and Babalola 2017; Yahaya et al. 2021). Therefore, metal contamination of the environment is a plausible occurrence through these activities, especially in sites close to these industrial activities. Snails purchased in the local market and eaten in these regions are often gathered from the wild and farmlands (Babatunde et al. 2019); however, studies have shown that snails gathered from farmlands close to industrial activities have a high accumulation of metals (Onuoha et al. 2016). Therefore, it is important to assess the effect of some metals on the toxicity and accumulation of local snail species in the area.

The land snail Archachatina papyracea is often found in garden soils throughout Nigeria. Therefore, a study assessing the effects of $\mathrm{Pb}$ and $\mathrm{Cd}$ in the local population of snails may be critical to assessing the environmental and human impact of the metal contamination in an area. For this study, we assessed the 
accumulation of $\mathrm{Pb}$ and $\mathrm{Cd}$, and the toxicity of these metals based on survival and weight change to the tropical snail species, A. papyracera. The choice of heavy metals, $\mathrm{Pb}$ and $\mathrm{Cd}$ used for this study was because $\mathrm{Pb}$ and $\mathrm{Cd}$, though non-essential metals, are often found in high concentrations in abandoned mining and smelting sites, and most industrial activities such as in the auto-mechanic industry (Dudka et al. 1995; Nica et al. 2012, Abidemi et al. 2011). Moreover, compared with other metals, the toxicity of cadmium and lead can be very high (Owojori and Siciliano 2012; Ziyou et al. 2016; Mahmutovic et al. 2018).

\section{Materials And Methods}

\section{Soil collection and preparation for experiment}

The soil sample used was a loamy soil collected from Ede Road, in lle-Ife, Nigeria. They were collected by scraping the first $5 \mathrm{~cm}$ topsoil from the site. The soil was oven-dried for seven days to defaunate it, and the physicochemical properties of the soils such as soil texture, water holding capacity (WHC), pH, and organic matter (OM) were subsequently determined using methods described by Jaabiri Kamoun et al. (2018). The soil was re-moistened to $50 \%$ of its maximum water holding capacity (WHC) and used for the acclimatization of the snails to laboratory conditions. During acclimatization, the snails were fed with fresh vegetables collected from a site where no pesticides were used at the Obafemi Awolowo University lle Ife, Nigeria. The physicochemical properties are summarized (Table 1).

Table 1 Physiochemical properties of the soil sample collected from Ede Road lle-lfe which was used for the toxicity experiments

\begin{tabular}{|cc|}
\hline Soil properties & Values \\
\hline Clay & $23 \%$ \\
Silt & $18 \%$ \\
Sand & $59 \%$ \\
\hline $\mathrm{pH}\left(\mathrm{H}_{2} \mathrm{O}\right)$ & 7.4 \\
\hline Organic matter & 7.8 \\
\hline Organic carbon & 4.6 \\
\hline
\end{tabular}

\section{Test animals and acclimatization}

The test animals used in the laboratory experiments were specimens of the indigenous land snail, Archachatina papyracea. The snails were purchased from the Kings market, lle-lfe, Nigeria. The snails within weight ranges of $8.5-10.5 \mathrm{~g}$ were selected for all the bioassays. The live snails were taken to the laboratory to acclimatize to laboratory conditions $\left(28 \pm 2^{\circ} \mathrm{C} ; 80-95 \pm 2 \%\right.$ Relative Humidity) in a plastic 
bucket terrarium $(200 \mathrm{~cm} \times 80 \mathrm{~cm} \times 30 \mathrm{~cm})$ containing a layer of moist humus soil as the substrate for at least 7 days before commencement of bioassays. The bucket terrarium was covered with a lid to prevent the snails from crawling out. The lids were perforated for proper ventilation. The snails were fed ad libitum on fresh pawpaw leaves (Carica papaya). Unconsumed food and faecal material were removed daily to prevent contamination. The snails used throughout the experiment were obtained from the same source to reduce the variability of the biotype.

\section{Test procedures}

The metals used for this experiment are lead added as lead sulphate $\left(\mathrm{PbSO}_{4} \cdot 5 \mathrm{H}_{2} \mathrm{O}\right.$; purity, $\left.98 \%\right)$ and cadmium added as cadmium chloride $\left(\mathrm{CdCl}_{2} \cdot 2 \frac{1}{2} \mathrm{H}_{2} \mathrm{O}\right)$. Pre-determined amounts of the metals were weighed using an analytical balance and made up to a fixed volume by adding an appropriate volume of distilled water as diluents to achieve a stock solution of known strength. The resultant stock was then serially diluted to obtain solutions of the required concentration. The concentrations of the $\mathrm{Pb}$ and $\mathrm{Cd}$ used were as follows: (1500, 3000, 6000, 12000, mg/kg Pb) and (15, 30, 60 and $120 \mathrm{mg} / \mathrm{kg} \mathrm{Cd})$. The concentrations used were chosen after a range-finding test. Each treatment soil $(2400 \mathrm{~g})$ was split into 3 equal portions and was put into different containers. Each of the samples containing $800 \mathrm{~g}$ dry weight soil was placed in a properly labelled cylindrical plastic vessel of $4 \mathrm{~L}$ and allowed to equilibrate for seven days before snails were introduced. Ten snails per container were used in each exposure regime and were introduced into the relevant test soil by placing them on the soil surface. The test containers were covered with a perforated lid to limit water loss due to evaporation and kept in $16 \mathrm{~h}$ light and $8 \mathrm{~h}$ dark at $28 \pm 2^{0} \mathrm{C}$ for 28 days. To maintain the snails during the exposure period in the test medium, the snails in each container were fed weekly with $100 \mathrm{~g}$ of Carica papaya (pawpaw) leaves. Uneaten food materials were removed weekly before adding new food items. Sampling was done weekly for weight change and survival. On the last day of the experiment, surviving worms were de-shelled and used for the metal analysis.

\section{Bioassay}

On each sampling occasion, weight change and mortality were assessed while $\mathrm{Pb}$ and $\mathrm{Cd}$ accumulation were only assessed at day 28 . Weight change was determined by collectively weighing all snails in each container and comparing the mean weight with initial values. Mortality was assessed by stimulating the snail with a blunt probe and the snail was judged dead if no response could be observed. To determine the amount of metal accumulated, one snail per container was selected and were placed on moist filter paper in petri dishes for $24 \mathrm{hrs}$ at $20^{\circ} \mathrm{C}$ to allow depuration of their gut contents. Afterwards, they were deshelled and frozen individually for metal analysis. The procedure for the metal extraction and analysis has been described by Maboeta et al. (2003). This was done by acid digestion with $\mathrm{HNO}_{3}$ and spectrophotometric analysis.

\section{Lead and cadmium accumulation analyses}


The acid digested snail samples and three blanks were analyzed for $\mathrm{Pb}$ and $\mathrm{Cd}$ by a Varian AA-1275 flame atomic absorption spectrophotometer (AAS) at the Central Science Laboratory, Obafemi Awolowo University, lle-Ife. To determine the $\mathrm{Pb}$ and $\mathrm{Cd}$ concentrations in the acid digested snail samples, the absorbances of $\mathrm{Pb}$ and $\mathrm{Cd}$ standards (Perkin Elmer Pure) were compared to the concentrations in the digested samples. For quality control, blanks, duplicates, and calibration standards were run for every five samples.

\section{Statistics}

The mortality and weight change data were presented as mean \pm standard deviation (SD). The survival was assessed as lethal concentration. The lethal concentrations at which $50 \%$ mortality of the snail population was observed (LC50), for each metal was calculated using the Trimmed Spearman Karber (TSK) method (USEPA 1993). The effective concentrations of the metals causing $50 \%$ or $25 \%$ reduction in snail weight (EC50) was estimated with non-linear regression models (3-parameter logistic models) in R (Ritz 2016).

\section{Results}

\section{Survival of the snails to $\mathrm{Pb}$ and $\mathrm{Cd}$}

The mortality of the snails increased with increasing concentration of Pb (Fig. 1). The numbers of snail in the control experiment remained relatively constant throughout the experiment. At day 7, no noticeable difference in survival was found for all $\mathrm{Pb}$ concentrations. However, by day 14 through day 28, a progressive effect of $\mathrm{Pb}$ on the survival of the snails was obvious. This progressive effect of $\mathrm{Pb}$ on the snails was evident in the LC50 values recorded after day $14(2786 \pm 852 \mathrm{mg} / \mathrm{kg})$, which was higher than at day $28(1121 \pm 457 \mathrm{mg} / \mathrm{kg})$ (Table 2). For Cd, at day 7, the dose-dependent effect of Cd was observed earlier than for $\mathrm{Pb}$, as $\mathrm{Cd}$ had more than $20 \%$ effect on mortality (LC25 $=84 \pm 8.50 \mathrm{mg} / \mathrm{kg}$ ) at the highest exposure concentration. As the duration of exposure increased from 7 to 14 days, the toxicity of $\mathrm{Cd}$ to the snails increased (Fig. 2). The toxic response of the snails to $\mathrm{Cd}$ was not different from day 14 to day 28 , and the LC50 values were also similar at day 14 and day 28 ( $86 \pm 3.5$ and $93 \pm 4.4 \mathrm{mg} / \mathrm{kg}$, respectively) (Table 2). 
Table 2

The LC50 and LC25 values \pm SE of Pb and Cd on survival of $A$. papyracea exposed in Nigerian loamy soil at day 7,14, 21 and 28 days

\begin{tabular}{|lllll|}
\hline Duration of Exposure (Days) & $\mathrm{Pb}$ & \multicolumn{3}{l|}{ Cd } \\
\cline { 2 - 5 } & $\mathrm{LC50}(\mathrm{mg} / \mathrm{kg})$ & $\mathrm{LC25}(\mathrm{mg} / \mathrm{kg})$ & $\mathrm{LC50}(\mathrm{mg} / \mathrm{kg})$ & $\mathrm{LC25}(\mathrm{mg} / \mathrm{kg})$ \\
\hline 7 & - & - & $181 \pm 21$ & $84 \pm 8.50$ \\
\hline 14 & $2786 \pm 852$ & $1045 \pm 569$ & $86 \pm 3.50$ & $58 \pm 3.54$ \\
\hline 21 & $1791 \pm 896$ & $439 \pm 434$ & $90 \pm 4.45$ & $65 \pm 5.00$ \\
\hline 28 & $1121 \pm 457$ & $372 \pm 268$ & $93 \pm 4.37$ & $70 \pm 5.11$ \\
\hline
\end{tabular}

Weight change of snails exposed to $\mathrm{Pb}$ and $\mathrm{Cd}$

Similar to the effect on survival at day 7 , there was no substantial effect on weight change at day 7 , as the concentration of $\mathrm{Pb}$ increased (Fig. 3). As from day 14, dose-dependent effect of $\mathrm{Pb}$ was seen on the weight change of the snails with the highest effect found at day 28. There is a drastic change in weight of the animals from day 7 to 28 (Figure 3). There was no effect of $\mathrm{Cd}$ on the weight of the snails up until day 7 at all the concentrations tested (Fig. 4). However, about $25 \%$ effect on snail weight started showing from day 14 but only at the highest concentration of $\mathrm{Cd}$. Toxicity of $\mathrm{Cd}$ on snail weight did not change as the duration of exposure increased from 14 to 28 days (EC25 $120 \mathrm{mg} / \mathrm{kg}$ ) (Table 3).

Table 3

The EC50 and EC25 values \pm SE of Pb and Cd on weight change of $A$. papyracea at day 7, 14, 21 and 28 days

\begin{tabular}{|lllll|}
\hline Duration of Exposure (Days) & $\mathrm{Pb}$ & \multicolumn{3}{l|}{ Cd } \\
\cline { 2 - 5 } & $\mathrm{EC50}(\mathrm{mg} / \mathrm{kg})$ & $\mathrm{EC} 25(\mathrm{mg} / \mathrm{kg})$ & $\mathrm{EC50}(\mathrm{mg} / \mathrm{kg})$ & $\mathrm{EC25}(\mathrm{mg} / \mathrm{kg})$ \\
\hline 7 & - & $7995 \pm 11277$ & - & - \\
\hline 14 & $5334 \pm 1130$ & $2618 \pm 757$ & $130 \pm 46.80$ & $120 \pm 3.37$ \\
\hline 21 & $4217 \pm 1792$ & $1177 \pm 919$ & $141 \pm 50.7$ & $123 \pm 10.50$ \\
\hline 28 & $4541 \pm 1180$ & $2640 \pm 1154$ & $131 \pm 41.23$ & $119 \pm 4.87$ \\
\hline
\end{tabular}

Other observations of the snails indicative of toxicity

From day 7, the snails were frequently seen clinging to the upper part of the container devoid of soil as a form of avoidance. At the end of the experiment, the number and size of eggs produced by snails in the contaminated soils were fewer and smaller than those in the control soils. Furthermore, when the snails 
were deshelled in readiness for accumulation assay, the haemolymph of the snails in the contaminated soils was thick and dark in colour compared to light coloured haemolymph of snails in the control soils.

\section{Accumulation of $\mathrm{Pb}$ and $\mathrm{Cd}$ in the snails}

Generally, no dose-response effect was seen in the accumulation of $\mathrm{Pb}$ in the snails (Figure 5), but exposed snails had higher concentrations of $\mathrm{Pb}$ than unexposed snails. The $\mathrm{Pb}$ content of snails in any of the exposed soil was at least 35 times higher than those in the unexposed soil (Figure 5a). Conversely, in the case of $\mathrm{Cd}$ exposure, the accumulation followed a dose-response pattern except at the highest concentration $(120 \mathrm{mg} / \mathrm{kg}$ ) of exposure (Figure $5 \mathrm{~b}$ ).

\section{Discussion}

This study demonstrated that $\mathrm{Pb}$ and $\mathrm{Cd}$, two contrasting metals, are toxic to the tropical snail $A$. papyracea exposed to concentrations likely to be found in the environment. Although some studies have reported the toxicity of these two metals to other species of snails, the toxicity values they reported were lower than in our study, suggesting A. papyracea may be more sensitive than these species. Sahraoui et al. (2021) reported $20 \% \mathrm{H}$. aspersa mortality at $3300 \mathrm{mg}$ of $\mathrm{Pb} / \mathrm{kg}$ and $40 \%$ mortality at $2000 \mathrm{mg}$ of $\mathrm{Cd} / \mathrm{kg}$ of soil. In the same study, EC50 on growth ranged from $2397-4804 \mathrm{mg}$ of $\mathrm{Pb} / \mathrm{kg}$ and $327-591 \mathrm{mg}$ of Cd/kg of soil. Courdassier et al. (2000) reported EC50 of about $1000 \mathrm{mg}$ of Cd/kg of soil. However, studies on snails exposed to contaminated food reported higher values - EC50 >13,900 mg of Pb/kg in food (Laskowski and Hopkin 1996a; Gomot-De Vaufleury 2000), suggesting that exposure via soil may be a more important pathway for metal toxicity to snails.

Cadmium (Cd) was more toxic than $\mathrm{Pb}$ in this study. In many ecotoxicological studies, $\mathrm{Cd}$ is usually the most toxic metal to soil organisms (Zhiyou et al. 2016; Owojori and Siciliano 2015). The comparatively lower $\mathrm{Pb}$ toxicity may be due to its low ability to cross membranes of exposed organisms. Studies have also shown that animals can accumulate $\mathrm{Pb}$ without any adverse effect (Otitoloju et al. 2009). It appears strange that the EC50 for weight change is higher than the LC50 for survival, but this could have been caused by the fact that only surviving snails were used to estimate weight change and therefore, the surviving snails could have been those avoiding the $\mathrm{Pb}$ in the substrate. Avoidance mechanisms, where soil organisms move away from contaminated food or soil, are well pronounced (Owojori et al. 2009b). Also, Laskowski and Hopkin (1996) reported that the intrinsic growth rate of $H$. aspersa populations was influenced more by delayed sexual maturity than by fecundity inhibition. The EC20 fecundity of $\mathrm{Pb}$ on $\mathrm{H}$. aspersa was 6140 ppm and for Cd was 120 ppm (Lakowski and Hopkin 1996b), values close to what we found in this study for effect on growth at that effect level.

Apart from data on the general trend in survival and weight change of snails after exposure to $\mathrm{Pb}$ and $\mathrm{Cd}$, other significant changes in the behaviour or physiology of the exposed snails were observed. The animals tended to move away from the contaminated soils to the upper part of the container. The number of eggs produced was fewer and smaller when compared to those in the control experiment. Carbone and Faggio (2019) reported that $H$. aspersa did not transfer metals to their eggs, but the eggs were smaller in 
size (Beeby and Richmond 2001; Carbone and Faggio 2019). Although we did not assess metal deposition in the eggs, the eggs produced in contaminated soils were smaller than eggs from the control soil. It is possible that the snails fed poorly, resulting in smaller egg production. For example, snails, Alinda biplicata exposed to high Cd concentration of about $2692 \mu \mathrm{g} / \mathrm{g}$ started feeding poorly at the onset of the study to avoid metal uptake, and they stopped consuming food by the end of the study (PedriniMartha et al. 2020). Many snails exposed to deleterious metal levels have been reported to avoid metal uptake by reducing food consumption (Lakowski and Hopkin 1996; Notten et al. 2006; El-Gendy et al. 2011). Another observation of the snails in our study was that the heamolymph of the snails in the control soils were light, with slight change in colour than the ones in the exposed soils, which were thick with darkened colouration. Otitoloju et al. (2009) reported the thickening and inflammation of hepatic tubules of the hepatocytes of $A$. marginata exposed to copper and lead.

In terms of metal accumulation, the snails accumulated $\mathrm{Pb}$ and $\mathrm{Cd}$ to varying degrees. It is consistent with many studies that reported significant metals accumulation by snails (Nica et al. 2012; PedriniMartha et al. 2020). Compared to $A$. marginata, our study showed that $A$. papyracea accumulated more $\mathrm{Pb}(38 \mu \mathrm{g} / \mathrm{g})$ and $\mathrm{Cd}(8 \mu \mathrm{g} / \mathrm{g})$ than observed in field studies with $A$. marginata. For example, $\mathrm{Pb}$ in the range of $0.77 \mathrm{mg} / \mathrm{kg}$ to $7.51 \mu \mathrm{g} / \mathrm{g}$ were reported in snails (A. marginata) sampled from nine sites in southern Nigeria (Chukwujindu et al. 2008). Ebenso and Ologhobo (2008) reported $\mathrm{Pb}$ accumulation ranging from $0.14-8.42 \mu \mathrm{g} / \mathrm{g}$ in $A$. marginata exposed to lead vehicular fumes. A. marginata collected from the field in six Nigerian states accumulated averages of $0.8 \mu \mathrm{g} / \mathrm{g}$ of $\mathrm{Pb}$ and $0.6 \mu \mathrm{g} / \mathrm{g}$ of $\mathrm{Cd}$ per snail (Wegwu and Wigwe 2006). However, Otitoloju et al. (2009) in a laboratory study reported a higher accumulation of $\mathrm{Pb}(67 \mu \mathrm{g} / \mathrm{g})$ in A. marginata than A. papyracea $(38 \mu \mathrm{g} / \mathrm{g})$ in our study. The high accumulation observed by Otitoloju et al. (2009) was probably because it is a laboratory study as the present stduy, and the method of application showed that both food and soil could have been dosed. However, in our study, only soil was dosed. Moreover, the increased accumulation of $\mathrm{Pb}$ or $\mathrm{Cd}$ in the laboratory studies showed that laboratory studies might over-exaggerate the accumulation of metals by snails in the wild, perhaps due to bioavailability differences or increased propensity of snails in the wild avoid contamination owing to a larger landscape.

Land snails belonging to the family Achatinidae are native to Africa (Awodiran et al. 2013). Many snail genera such as Archachatina belonging to this family are often consumed as food in Nigeria. Their meat is proteinous with low cholesterol and contains vital minerals making them nutritious (Awodiran et al. 2013; Onuoha et al. 2016). Therefore, snails can also be a source of human health concern in Nigeria if contaminated snails are consumed (Onuoha et al. 2016). This study has revealed that the non-essential metals, $\mathrm{Pb}$ and $\mathrm{Cd}$, are harmful to the snail Archachatina papyracea and that this snail species could accumulate both metals in their tissues. Since the snails accumulated $\mathrm{Pb}$ and $\mathrm{Cd}$ in this laboratory experiment, it is an indication that snails in the wild could also accumulate $\mathrm{Pb}$ or $\mathrm{Cd}$ if their environment is contaminated with these metals. Therefore, snails picked in these areas and sold in the market might pose a severe health risk to humans. Due to a possible health impact from consuming contaminated snails, great care should be taken when such snails are bought in the market. For example, snails should be purged by not feeding for about 5 days before consuming the snails to detoxify pathogens and 
chemicals like metals (Antwi 2009). Apart from the human health risk associated with consuming contaminated snails, the ecological status and preserving their biodiversity is also vital. We hereby advocate that more metal accumulation and toxicity studies on snails need to be conducted for tropical snail species.

\section{Conclusion}

In this study, A papyracea (based on survival and growth) is more sensitive to $\mathrm{Pb}$ and $\mathrm{Cd}$ compared to most studies on other snail species. A papyracea also accumulates $\mathrm{Pb}$ and $\mathrm{Cd}$ to a higher degree than most reported in literature exposed to similar concentrations. Physiological effect such as darkened haemolymph and sublethal manifestations such as decreased egg size and production were observed in the exposed snails. Moreover, because of the propensity of $A$. papyracea to accumulate substantial concentration of metals from the environment, purging of the snails is advised prior to human consumption. The study showed that $A$. papyracea is suitable for use as a soil biological indicator of toxic metals in the tropics, such as in Nigeria.

\section{Declarations}

\section{Acknowledgements}

We acknowledge that the abstract and data for this study was first presented as a poster at the Society of Environmental Toxicology and Chemistry (SETAC) $6^{\text {th }}$ World Congress, Berlin, Germany in 2012 and grateful for various feedbacks during the presentation.

\section{Author contributions}

Olugbenga John Owojori Project administration, method, validation, formal analysis, and investigation, visualization, writing-original draft, and writing-review and editing.

Michael Awodiran Analytical method validation, investigation, writing-review and editing.

Oluwadunsin Ajana Analytical method validation, investigation, visualization, writing-original draft

Olukayode Oluwole Jegede Analytical method validation, formal analysis, writing-original draft, writingreview and editing and visualization.

Funding Not applicable

Availability of data and materials The datasets used and/or analyzed during the current study are available from the corresponding author on reasonable request.

Ethics approval and consent to participate Not applicable.

Consent to publish Not applicable. 
Competing interests The authors declare no competing interests.

\section{References}

1. Abidemi OO (2011) Levels of $\mathrm{Pb}, \mathrm{Fe}, \mathrm{Cd}$ and $\mathrm{Co}$ in soils of automobile workshop in Osun State, Nigeria. JASEM 15 (2)

2. Adeyi AA, Babalola BA (2017) Lead and cadmium levels in residential soils of Lagos and Ibadan, Nigeria. J Health Pollut 7(13):42-55

3. Antwi S (2009) Innovative methods for processing snail (Achatina achatina) meat powder of high microbiological and sensory qualities (Doctoral dissertation)

4. Awodiran MO, Awopetu Jl, Odekanyin OO, Ogunbosoye DO (2013) An electrophoretic study of protein diversity in five species of land snails (Achatinidae) from Nigeria. IJBCS 7:86-95

5. Babatunde TO, Kehinde AS, Babatunde 00 (2019) Marketing analysis of snail in selected market in Ibadan metropolis, Oyo state, Nigeria. Journal of Research in Forestry Wildlife Environment 11:106113

6. Beaby A, Eaves SL (1983) Short term changes in ( $\mathrm{Pb}, \mathrm{Zn}$ and $\mathrm{Cd}$ concentrations of the garden Snail Helix aspersa (Muller) from a central London Car Park. Environ Pollut 30:233-244

7. Beeby A, Richmond L (1989) The shell as a site of lead deposition in Helix aspersa. Arch Environ Contam Toxicol 18:623-628

8. Beeby A, Richmond L (2001) Calcium provision to eggs in two populations of Helix aspersa by parents fed a diet high in lead. J Molluscan Stud 67:1-6

9. Berger B, Dallinger R (1989) Accumulation of cadmium and copper by the terrestrial snail Arianta arbustorum L.: Kinetics and budgets. Oecologia 79:60-65

10. Bonally De calventi I (1965) Copper poisoning in the snail Helix pomania and its effects on mucous secretion. Ann N Y Acad Sci 118:1015-1020

11. Calabresse A, Thurberg FP, Gould E (1977) Effects of Cadmium, mercury and silver on marine animals. Mar Fish Rev 39:5-11

12. Carbone D, Faggio C (2019) Helix aspersa as sentinel of development damage for biomonitoring purpose: A validation study. Mol Reprod Dev 86:1283-1291

13. Chukwujindu MAl, Francis OA, Godwin EN, Osa E (2008) Heavy metal content in the African giant snail Archachatina marginata (Swainson, 1821) (Gastropoda: Pulmonata: Achatinidae) in Southern Nigeria. Folia Malacologica 16:31-34

14. Cikutovic MA, Fitzpatrick LC, Venables BJ, Goven AJ (1993) Sperm count in earthworms (Lumbricus terrestris) as a biomarker for environmental toxicology; effects of cadmium and chlordane. Environ Pollut 81:123-125

15. Cœurdassier M, Vaufleury AG, Badot PM (2000) Dose-dependent growth inhibition and bioaccumulation of hexavalent chromium in land snail Helix aspersa. Environ Toxicol Chem 19:2571-2578 
16. De Vaufleury AG, Pihan F (2000) Growing snails used as sentinels to evaluate terrestrial environment contamination by trace elements. Chemosphere 40:275-284

17. Dudka S, Piotrowska M, Chlopecka A, Witek T (1995) Trace metal contamination of soils and crop plants by mining and smelting industry in Upper Silesia South-West, Poland. J Geochem Explor 52:237-250

18. Ebenso IE, Ologhobo AD (2008) Effects of lead pollution from vehicular exhaust fumes against sentinel juvenile Achatina achatina. B Environ Contam Tox 81:513-515

19. Edwards CA (2002) Assessing the effects of environmental pollutants on soil organisms, communities, processes and ecosystems. European J Soil Biol 38:225-231

20. El-Gendy KS, Radwan MA, Gad AF (2011) Feeding and growth responses of the snail Theba pisana to dietary metal exposure. Arch Environ Contam Toxicol 60:272-280

21. Gimmler H, Carandang J, Boots A, Reisberg E, Woitke M (2002) Heavy metal content and distribution within a woody plant during and after seven years continuous growth on municipal solid waste (MSW) bottom slag rich in heavy metals. J Appl Bot 76:203-217

22. Gomot de Vaufleury A (2000) Standardized growth toxicity testing ( $\mathrm{Cu}, \mathrm{Zn}, \mathrm{Pb}$, and pentachlorophenol) with Helix aspersa. Ecotoxicol Environ Saf 46:41-50

23. Howard B, Mitchell PC, Ritchie A, Simkiss K, Taylor M (1981) The composition of intracellular granules from the metal-accumulating cells of the common garden snail (Helix aspersa). Biochem $\mathrm{J}$ 194:507-511

24. Jaabiri Kamoun I, Jegede O0, Owojori OJ, Bouzid J, Gargouri R, Römbke J (2018) Effects of deltamethrin, dimethoate, and chlorpyrifos on survival and reproduction of the collembolan Folsomia candida and the predatory mite Hypoaspis aculeifer in two African and two European soils. IEAM $14: 92-104$

25. Jones DT (1991) Biological Monitoring of Metal Pollution in Terrestrial Ecosystems. PhD thesis, University of Reading

26. Laskowski R, Hopkin SP (1996b) Effect of Zn, Cu, Pb, and Cd on fitness in snails (Helix aspersa). Ecotoxicol Environ Saf 34:59-69

27. Laskowski R, Hopkin SP (1996a) Accumulation of Zn, Cu, Pb and Cd in the garden snail Helix aspersa: implications for predators. Environ Pollut 91:289-297

28. Maboeta MS, Reinecke SA, Reinecke AJ (2003) Linking lysosomal biomarker and population responses in a field population of Apporectodea caliginosa (Oligochaeta) exposed to the fungicide copper oxychloride. Ecotoxicol Environ Saf 56:411-418

29. Mahmutovic H, Markovic R, Janjic J, Glamoclija N, Baltic B, Katanic N, Ciric J (2018) Concentration of arsenic and heavy metals in snail tissues. Meat Technol 59:75-79

30. Marigomez JA, Angulo E, Saez V (1986) Feeding and growth responses to copper, zinc, mercury and lead in the terrestrial gastropod Arionater(Linne). J Moll Stud 52:68-78 
31. Nica DV, Filimon MN, Bordean DM, Harmanescu M, Draghici GA, Dragan S, Gergen II (2015) Impact of soil cadmium on land snails: a two-stage exposure approach under semi-field conditions using bioaccumulative and conchological end-points of exposure. PloS one 10(3):e0116397

32. Notten MJM, Oosthoek AJP, Rozema J, Aerts R (2006) Heavy metal pollution affects consumption and reproduction of the land snail Cepaea nemoralis fed on naturally polluted Urtica dioica leaves. Ecotoxicology 15:295-304

33. Onuoha SC, Anelo PC, Nkpaa KW (2016) Human health risk assessment of heavy metals in snail (Archachatina marginata) from four contaminated regions in Rivers State, Nigeria. Ameri Chem Sci J 11:1-8

34. Otitoloju AA, Ajikobi DO, Egonmwan RI (2009) Histopathology and bioaccumulation of heavy metals $(\mathrm{Cu} \& \mathrm{~Pb})$ in the giant land snail, Archachatina marginata (Swainson). The Open Environmental Pollution Toxicology Journal 1:79-88

35. Owojori OJ, Siciliano SD (2015) The potentiation of zinc toxicity by soil moisture in a boreal forest ecosystem. Environ Toxicol Chem 34:600-607

36. Owojori OJ, Reinecke AJ (2009b) Avoidance behaviour of two eco-physiologically different earthworms (Eisenia fetida and Aporrectodea caliginosa) in natural and artificial saline soils. Chemosphere 75:279-283

37. Owojori OJ, Reinecke AJ, Rozanov AB (2009a) The combined stress effects of salinity and copper on the earthworm Eisenia fetida. Appl Soil Ecol 41:277-285

38. Owojori OJ, Siciliano SD (2012) Accumulation and toxicity of metals (copper, zinc, cadmium, and lead) and organic compounds (Geranial and Benzo(a)pyrene) in the oribatid mite Oppia nitens. Environ Toxicol Chem 31:1639-1648

39. Pedrini-Martha V, Köll S, Dvorak M, Dallinger R (2020) Cadmium uptake, MT gene activation and structure of large-sized multi-domain metallothioneins in the terrestrial door snail Alinda biplicata (Gastropoda, Clausiliidae). Int J Mol Sci 21:1631. doi:10.3390/ijms21051631

40. Reinecke SA, Reinecke AJ (1997) The influence of lead and Manganese on the spermatozoa of Eisenia fetida (Oligochaeta). Soil Biol Biochem 29:737-742

41. Ritz C (2016) Analysis of Dose-Response Curves. Version 3.0-1. 2016. URL http://www.rproject.orghttp://www.bioassay.dk. CRAN. 2016-08-30

42. Russell LK, DeHaven JI, Botts RP (1981) Toxic effects of cadmium on the Garden snail (Helix aspersa). Bull Environ Contam Toxicol 26:634-640

43. Sahraoui AS, Verweij RA, Belhiouani H, Cheriti O, Van Gestel CA, Sahli L (2021) Dose-dependent effects of lead and cadmium and the influence of soil properties on their uptake by Helix aspersa: an ecotoxicity test approach. Ecotoxicology 30:331-342

44. Spurgeon DJ, Hopkin SP, Jones DT (1994) Effects of cadmium, copper, lead and zinc on growth, reproduction and survival of the earthworm Eisenia fetida (Savigny): Assessing the environmental impact of point-source metal contamination in terrestrial ecosystems. Environ Pollut 84:123-130 
45. Taylor MG, Simkiss K, Greaves GN, Harries J (1988) Corrosion of intracellular granules and cell death. Proc. R. Soc. London B 234: 463-467

46. Ugokwe CU, Okafor FC, Okeke PC, Ezewudo BI, Olagunju TE (2020) Induction of genetic alterations and oxidative stress in giant African land snail (Limicolaria aurora) exposed to municipal waste leachate. Rev Toxicol 19-25

47. USEPA (1993) A Linear Interpolation Method for sub-lethal toxicity: the inhibition concentration (ICp) Approach (Version 2.0) National Effluent Toxicity Assessment Center Technical Report 03-93

48. Wang K, Qiao Y, Zhang H, Yue S, Li H, Ji X, Liu L (2018) Bioaccumulation of heavy metals in earthworms from field contaminated soil in a subtropical area of China. Ecotoxicol Environ Saf 148:876-883

49. Wegwu MO, Wigwe IA (2006) Trace-Metal Contamination of the African Giant Land Snail Archachatina marginata from Southern Nigeria. Chem Biodiverse 3:88-93

50. Yahaya SM, Abubakar F, Abdu N (2021) Ecological risk assessment of heavy metal-contaminated soils of selected villages in Zamfara State, Nigeria. SN Applied Sciences 3(2):1-13

51. Yakeem A, Onifade TO (2012) Evaluation of some heavy metals in soils along major roads in Ogbomoso, South West Nigeria. J Environ Earth Sci 2(8)

52. Zayed A, Lytle CM, Qian JH, Terry N (1998) Chromium accumulation, translocation and chemical speciation in vegetable crops. Planta 206:293-299

53. Zhiyou FU, Fengchang WU, Chen L, Bingbing XU, Feng C, Bai Y, Liao H, Sun S, Giesy JP, Guo W (2016) Copper and zinc, but not other priority toxic metals, pose risks to native aquatic species in a large urban lake in Eastern China. Environ Pollut 219:1069-1076

\section{Figures}



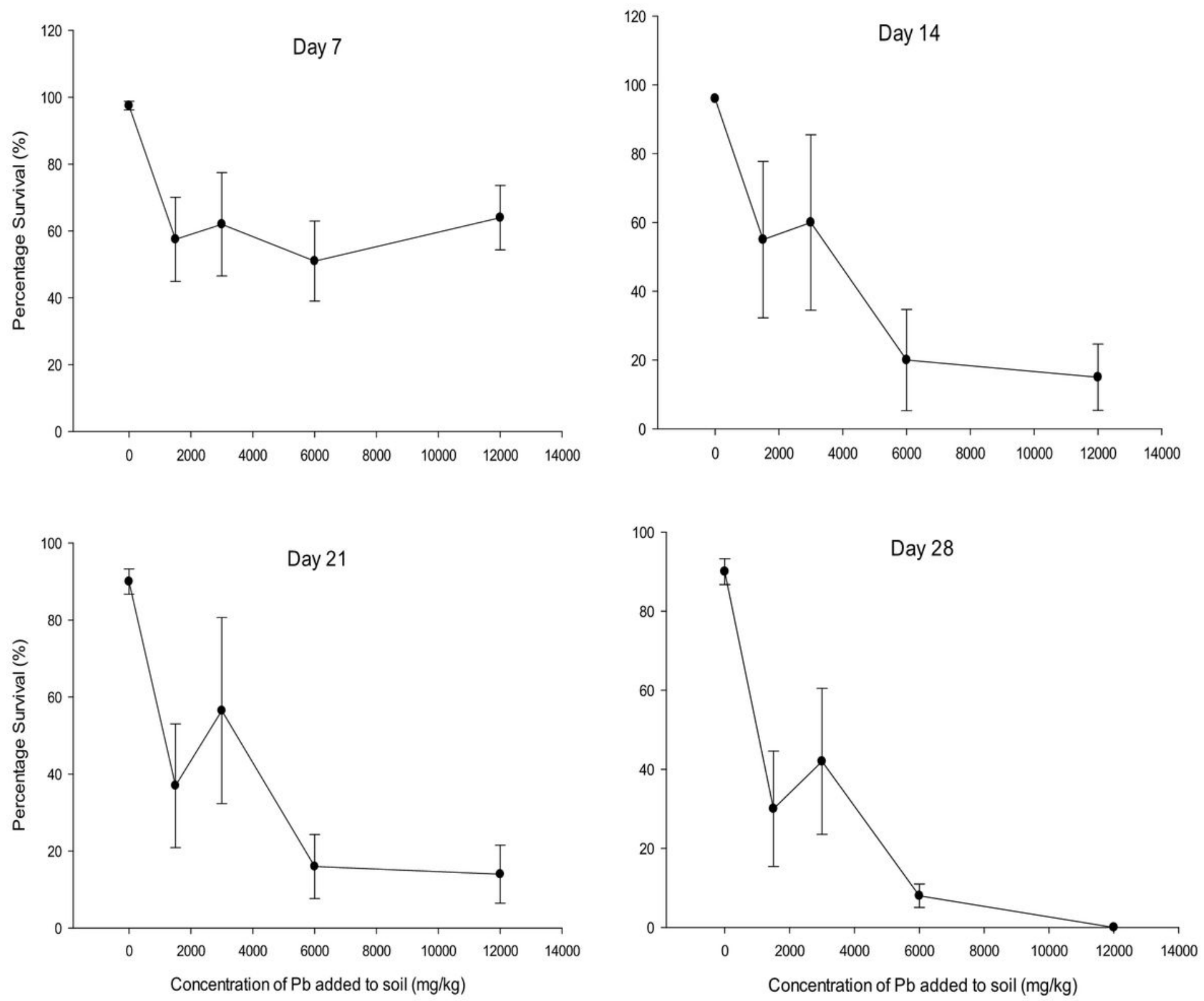

\section{Figure 1}

Mean $( \pm S D)$ survival of ten snails (Archachatina papyracea) in Nigerian loamy soil contaminated with $\mathrm{Pb}$ ( $\mathrm{mg} / \mathrm{kg}$ of soil) under laboratory conditions after $7,14,21$ and 28 days of exposure $(n=3)$ 

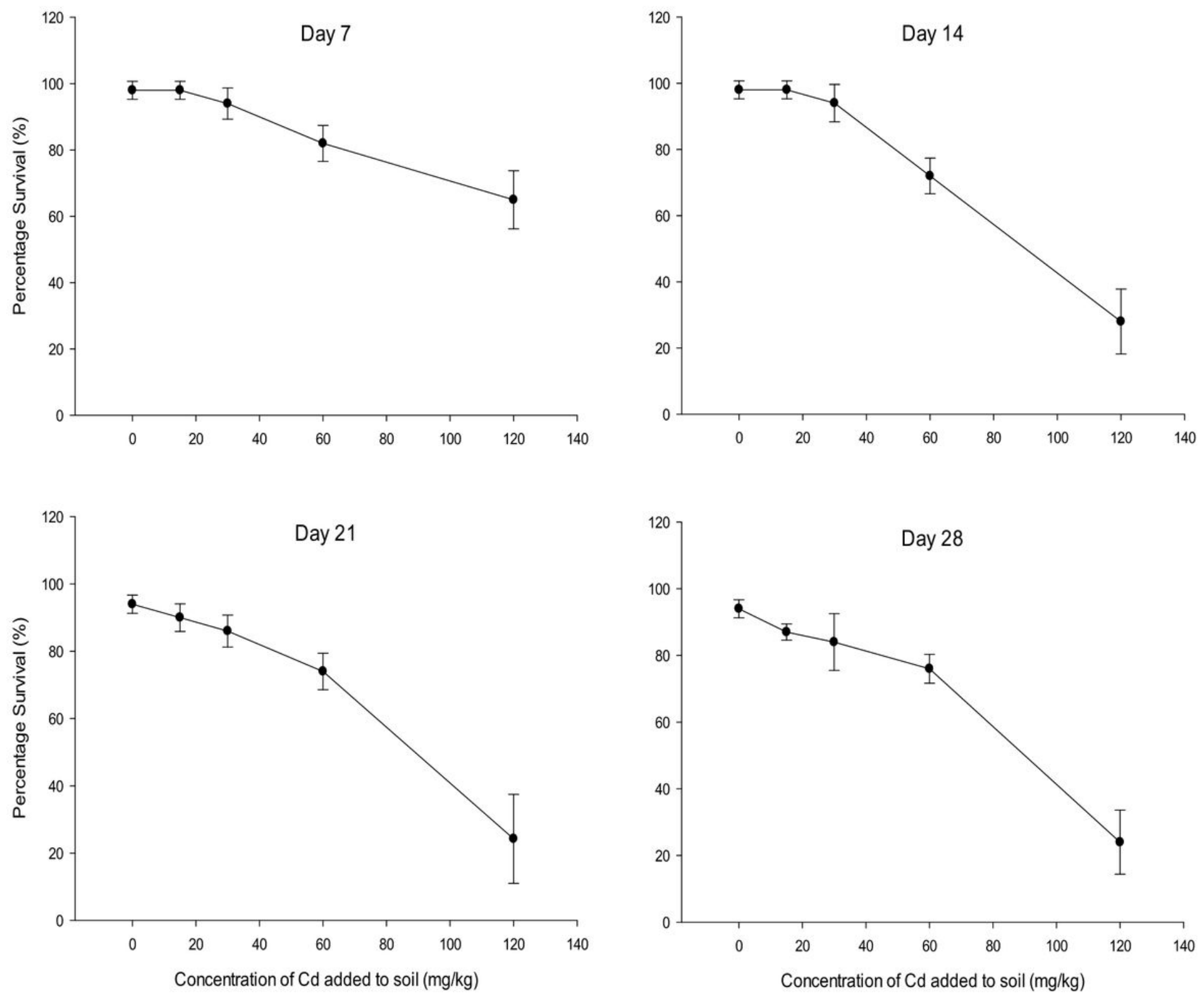

Figure 2

Mean ( $\pm S D$ ) survival of ten snails (A. papyracea) in Nigerian loamy soil contaminated with Cd under laboratory conditions after $7,14,21$ and 28 days of exposure $(n=3)$ 

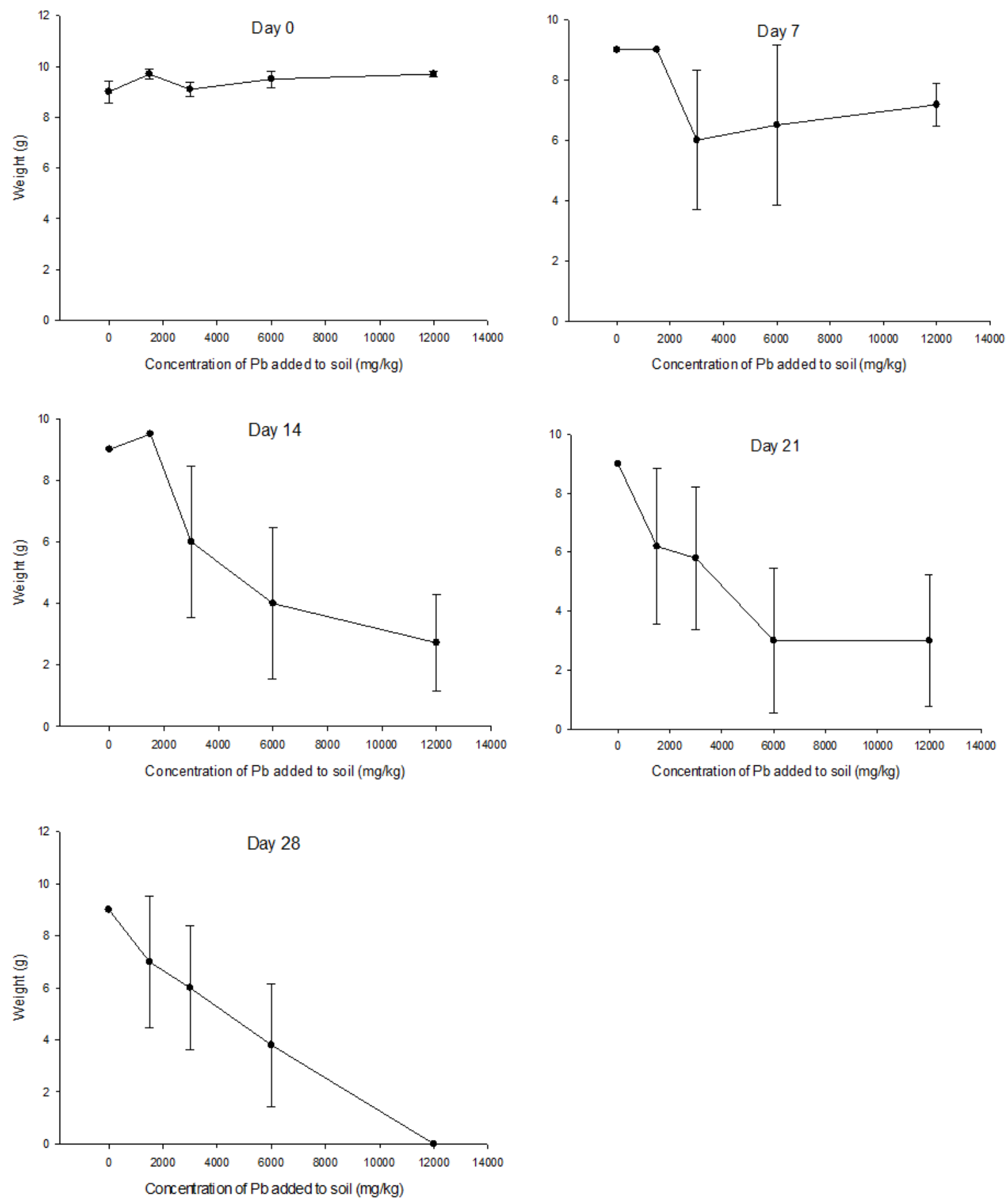

\section{Figure 3}

Mean $( \pm S D)$ weight change of ten snails (A. papyracea) in Nigerian loamy soil contaminated with $\mathrm{Pb}$ under laboratory conditions at day $0,7,14,21$, and 28 

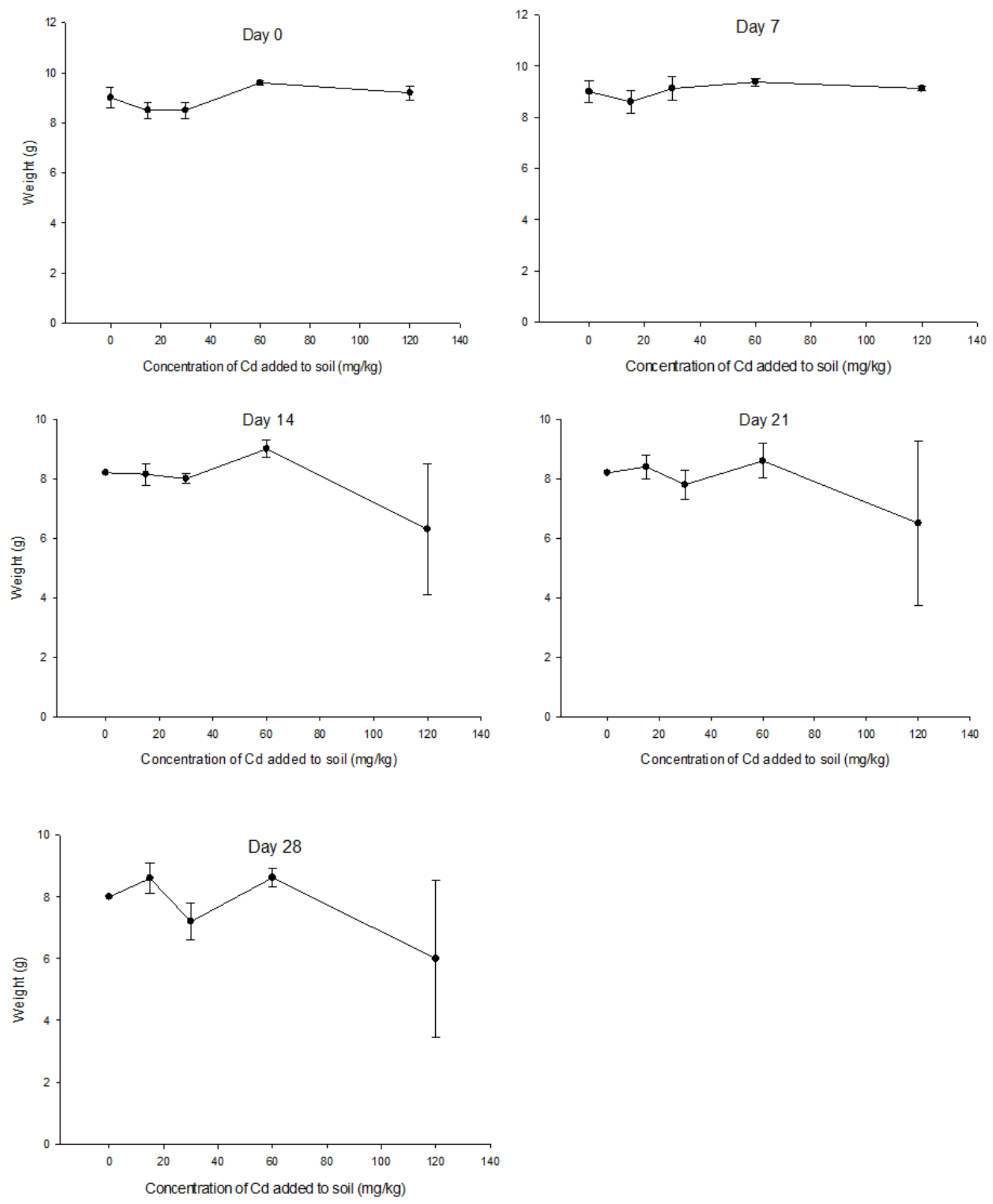

\section{Figure 4}

Mean $( \pm S D$ ) weight change of ten snails (A. papyracea) in Nigerian loamy soil contaminated with $\mathrm{Pb}$ under laboratory conditions at day $0,7,14,21$, and 28 


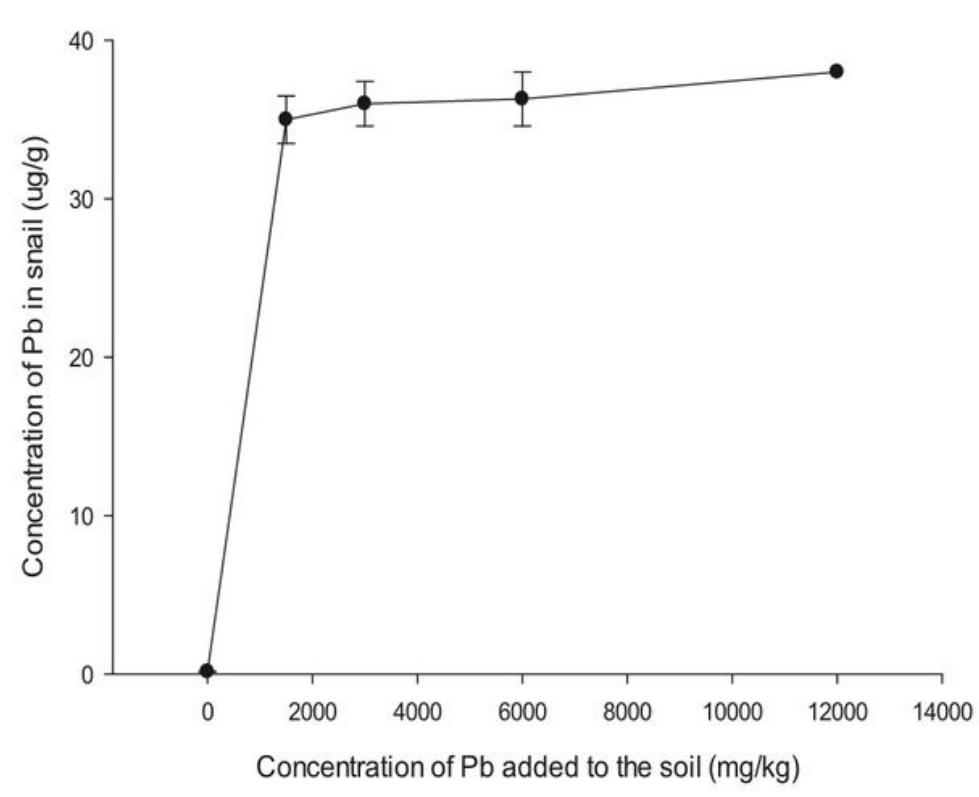

(a)

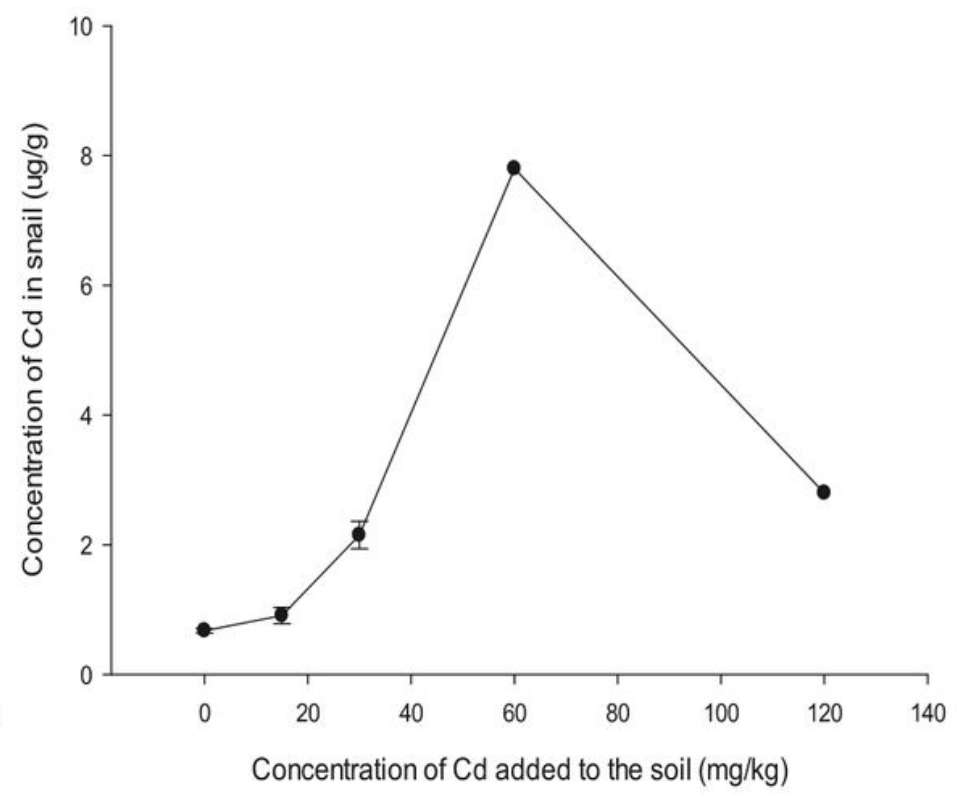

(b)

\section{Figure 5}

Mean ( \pm SD) concentration of (a) lead and (b) cadmium in $\mu \mathrm{g} / \mathrm{g}$ of snail Archachatina papyracea after exposure to varying concentrations of $\mathrm{Pb}$ and $\mathrm{Cd}$ in $\mathrm{mg} / \mathrm{kg}$ of Nigerian loamy soil after 28 days 